\title{
Combined Statin-Fibrate Therapy-Induced Rhabdomyolysis: Case Report
}

\author{
Tanja L. Jozić1, Branka M. Terzić1, Predrag M. Mitrović \\ Jasminka D. Kostić1, Marko Z. Milanov³, Milena M. Stojanović \\ Milika R. Ašanin ${ }^{2}$ \\ ${ }^{1}$ Clinic of Cardiology, Clinical Center of Serbia, Belgrade, Serbia; \\ 2 Faculty of Medicine, University of Belgrade, Belgrade, Serbia; \\ ${ }^{3}$ Emergency Center, Clinical Center of Serbia, Belgrade, Serbia
}

\section{SUMMARY}

Introduction Rhabdomyolysis is a rare, but serious and potentially fatal adverse reaction of the statin application that may be developed in any time of therapy. It is characterized by massive destruction of muscles associated with the large increase of creatine kinase (CK) leading to myoglobinuria and potential acute renal failure. Combined statin-fibrate therapy increases the risk of rhabdomyolysis, especially in elderly and diabetic patients.

Case report An 81-year-old male was admitted to Coronary Care Unit of the Emergency Center, Clinical Center of Serbia (CCS) with the clinical picture and electrocardiogram of the acute anterior wall myocardial infarction complicated with pulmonary edema. Laboratory tests on admission showed higher elevated values of serum creatinine $179 \mu \mathrm{mol} / \mathrm{L}$ and BUN 9.2 $\mathrm{mmol} / \mathrm{L}\left(\mathrm{eGFR} 32 \mathrm{~mL} / \mathrm{min} / 1.73 \mathrm{~m}^{2}\right.$ ), CK $309 \mathrm{U} / \mathrm{L}$ (on day $2: 3476 \mathrm{U} / \mathrm{L}$ ) and mixed hyperlipidemia (total cholesterol $10.3 \mathrm{mmol} / \mathrm{L}, \mathrm{HDL} 2.26 \mathrm{mmol} / \mathrm{L}, \mathrm{TG} 4.85 \mathrm{mmol} / \mathrm{L}$ ). The patient was treated with thrombolysis medication therapy (Alteplase), anticoagulant and dual antiplatelet therapy, diuretics, organic nitrates, angiotensin-converting enzyme (ACE) inhibitors, antibiotics, and proton pump inhibitors. During seven days, his therapy included combined pravastatin $20 \mathrm{mg}$ and fenofibrate ( $160 \mathrm{mg})$, which was discontinued due to pains and weakness of muscles and significantly elevated CC to $7080 \mathrm{U} / \mathrm{L}$ (upper limit $200 \mathrm{U} / \mathrm{L}$ ), but no significant deterioration of renal function was observed. Discontinuation of therapy resulted in CC level normalization and improvement of clinical condition.

Conclusion Combined statin and fibrate therapy requires strict clinical control and monitoring of CK i transaminases. Four-time or higher increase of CK requires discontinuation of therapy. In addition, patients are advised to report immediately any pains in muscles, sensibility, weakness or cramps.

Keywords: rhabdomyolysis; statins; fibrates 


\section{INTRODUCTION}

Rhabdomyolysis is a clinical syndrome characterized by necrosis of skeletal muscles with resulting release of toxic cell components into systemic circulation. The causes of rhabdomyolysis are multiple: metabolic myopathies, trauma, electrocution, excessive physical activity, infections, intoxication, hyperthermia, as well as use of specific drugs and their adverse interaction. Statins belong to the group of most studied medicines, and their benefit in treatment and prevention of cardiovascular and cerebrovascular diseases is definitely verified. In the last several decades, they were prescribed to millions of patients and besides efficacy, they confirmed good safety profile. Statin monotherapy is safe and well tolerated, with low frequency of adverse events. However, the conditions increasing the plasma statin concentration, such as higher doses or combined therapy may increase the risk of adverse events; it is estimated that approximately $50 \%$ of severe side effects of statin therapy is the consequence of interaction with other drugs. Most frequent side effect is myopathy characterized by muscle pain and/or weakness, but it may rarely cause muscular necrosis and rhabdomyolysis. Combined statin and fibrate treatment may increase the risk of rhabdomyolysis, especially in elderly people and diabetics.

The case report on combined statin-fibrate therapy-induced rhabdomyolysis is here presented to evaluate the significance of early diagnosis and adequate intensive therapy.

\section{CASE REPORT}

An 81-year-old male was admitted to Coronary Care Unit of the Emergency Center, Clinical Center of Serbia (CCS) with the clinical picture and electrocardiogram of the acute anterior wall myocardial infarction complicated with pulmonary edema. His personal medical history reported stable angina 2-3 months before presentation, cholelithiasis and surgery for the left kidney calculosis 21 years ago. He did not receive any therapy.

On physical examination, the patient was conscious, oriented, orthodispnoic, afebrile, and obese. On lung auscultation, prolonged expirium with diffuse rales to the scapulas corresponding to pulmonary edema was heard. The heart rate was regular at 130 beats $/ \mathrm{min}$, gal- lop rhythm, without murmurs; blood pressure was $210 / 140 \mathrm{mmHg}$ bilaterally. The abdomen was soft, painless on palpation, without hepatosplenomegaly. He had no peripheral edema, and peripheral arterial pulsations were symmetrically palpable. On admission, ECG showed sinus rhythm and ST-segment elevations in leads V1-V6. In further course, an evolution of the anterior wall myocardial infarction was ECG recorded.

On admission, laboratory tests were as follows: glycemia $10.7 \ldots .5 .5 \mathrm{mmol} / \mathrm{L}$; urea 9,2 $\mathrm{mmol} / \mathrm{L}$; creatinine (Cr) $179 \mu \mathrm{mol} / \mathrm{L}$; eGFR 32 $\mathrm{mL} / \mathrm{min} / 1.73 \mathrm{~m}^{2}$; sodium $140 \mathrm{mmol} / \mathrm{L}$; potassium $4.2 \mathrm{mmol} / \mathrm{L}$; chlorine $104 \mathrm{mmol} / \mathrm{L}$; AST $34 \mathrm{U} / \mathrm{L}$, ALT $17 \mathrm{U} / \mathrm{L}, \mathrm{CK} 309 \mathrm{U} / \mathrm{L}$, troponin I $0.828 \mathrm{ug} / \mathrm{L}, \mathrm{Hgb} 168 \mathrm{~g} / \mathrm{L}$, hematocrit 0.50 , WBC $20.9 \times 10^{9} / \mathrm{L}$, platelets $192 \times 10^{9} / \mathrm{L}$, fibrinogen $>3,7 \mathrm{~g} / \mathrm{L}$, ESR $8 \mathrm{~mm} / \mathrm{h}$, total cholesterol 10.3 $\mathrm{mmol} / \mathrm{L}, \mathrm{HDL} 2.26 \mathrm{mmol} / \mathrm{L}$, and triglycerides $4.85 \mathrm{mmol} / \mathrm{L}$.

Upon admission, the patient was treated with diuretics (i.v. furosemide), nitroglycerin (NTG) infusion, dual antiplatelet therapy (aspirin and clopidogrel), and proton pump inhibitors as a protection; after normalization of blood pressure, thrombolytic therapy (i.v. alteplase $100 \mathrm{mg}$ ) and heparin infusion were administered. This resulted in significant clinical improvement of cardiac status in terms of regression of symptoms and signs of the heart failure, but an early hospital course was complicated by fever (since day 3 ) and verified right-sided pneumonia and urinary infection. The chest X-ray demonstrated the left pleural exudation, the right mediobasal pulmonary parenchyma consolidation and cardiomegaly with hilar stasis. Echocardiography showed normal size of the left ventricle with concentrically hypertrophic walls, akinesia of medial septum, anterior and lateral wall and apex, and reduced systolic function (EF 40\%).

Besides anticoagulant and dual antiplatelet therapy, diuretics (furosemide and spironolactone), nitrates and proton pump inhibitors, angiotensin-converting enzyme (ACE) inhibitor (fosinopril) and antibiotics were introduced in therapy, as follows: initially ceftriaxone, later on replaced by ertapenem and ciprofloxacin for urinary infection and isolated Enterobacter spp. in the urine culture. Blood cultures were sterile. Due to mixed hyperlipidemia, the patient was initially administered rosuvastatin, but because of its shortage in our hospital, pravastatin 20 $\mathrm{mg}$ and fenofibrate $160 \mathrm{mg}$ were included on 
day 3 of hospitalization. Since day 3 of his stay, he complained exclusively on pains in joints, at first in the knees and then ankles, and the following days were featured by progressive pain in leg muscles and inability to move them.

Neurological status: the impression of bilateral paratonia; upon upper extremities examination - sinking with pronation of both hands, more to the right; MR were more intensive bilaterally; lower extremities - no ability of moving his legs, MR bilaterally extinguished, bilateral "silent" soles of the feet. Laboratory analyses revealed markedly elevated $\mathrm{CK}$ to maximum $7080 \mathrm{U} / \mathrm{L}$ (Graph 1), elevated BUN and serum creatinine from the baseline level (Graph 2), hyperkaliemia with max. $5.6 \mathrm{mmol} / \mathrm{l}$ along with

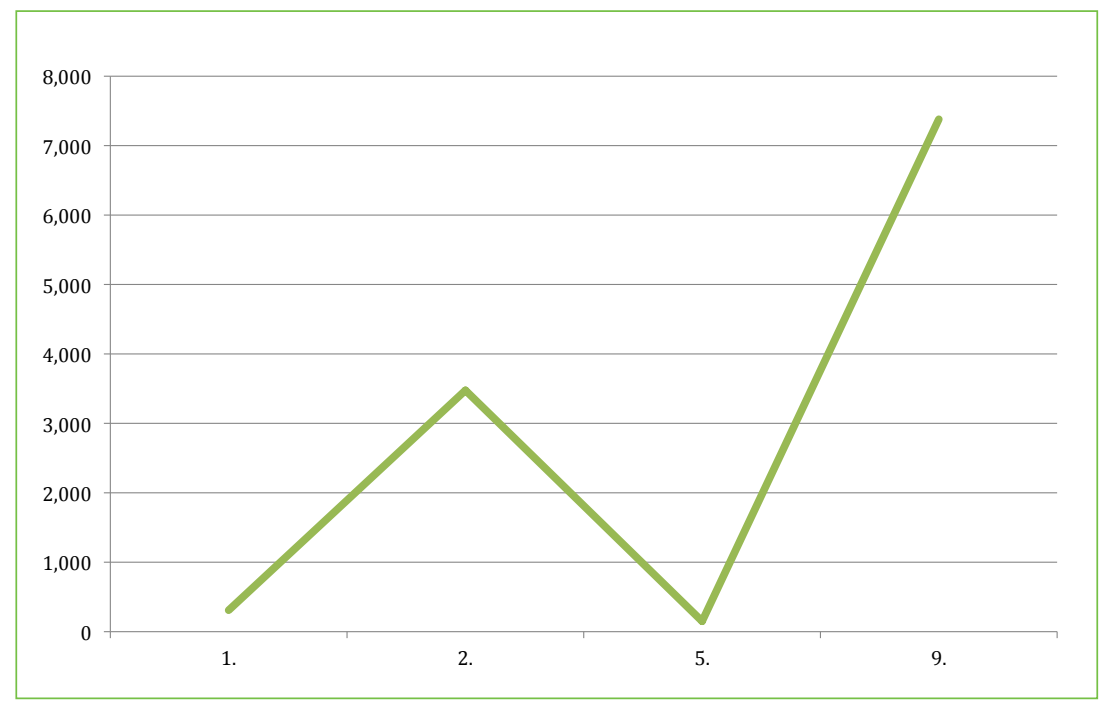

Graph 1. CK values during hospitalization

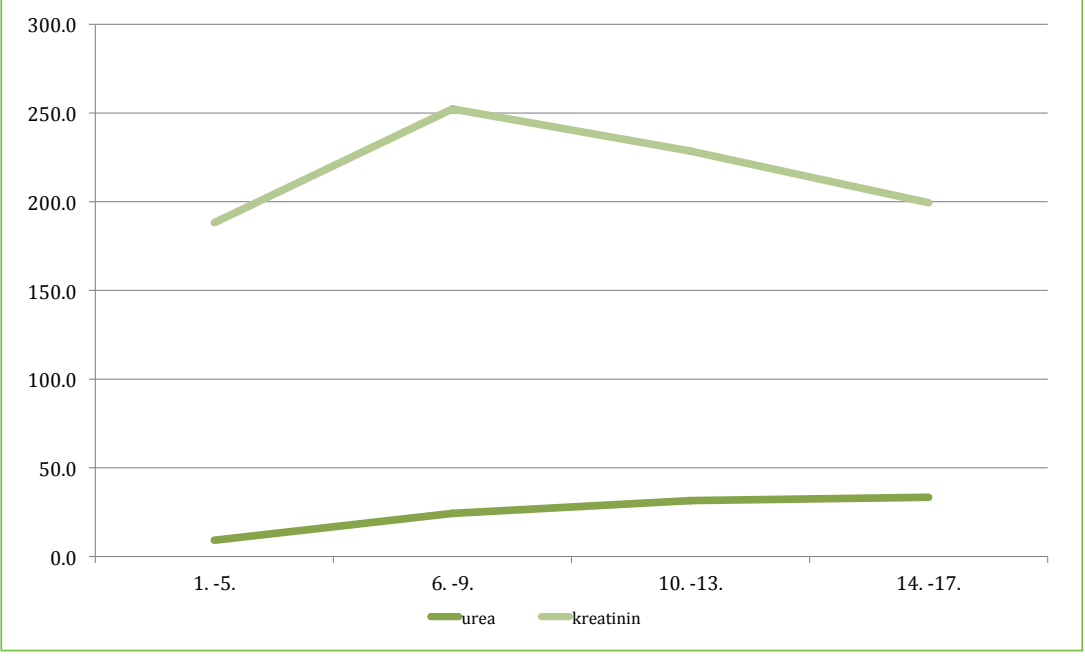

Graph 2. Values of nitrogen substances (urea and creatinine) during hospitalization hyponatremia (124 mmol/l) and hypochlore$\mathrm{mia}(86 \mathrm{mmol} / \mathrm{l})$, as well as positive inflammatory syndrome. The urine analysis was negative for myoglobin.

Given the clinical picture and laboratory parameters indicating the statin-induced rhabdomyolysis, pravastatin and fenofibrate treatment (applied 7 days) was discontinued, which, together with symptomatic measures, first of all intensive rehydration of patient, led to clinical improvement in view of complete resolution of muscular symptoms and restoration of $\mathrm{CK}$ and BUN and serum creatinine to baseline levels. The patient was discharged in a stable condition with, among others, diagnosis of medicamentous myopathy.

\section{DISCUSSION}

The most common complication of statin use is different skeletal muscle side effects that may be generally designated as statin-induced myopathy (Table 1).

According to data of randomized clinical studies and registries, the incidence of myopathy is estimated as 5 patients/100,000 individuals/year, and rhabdomyolysis as 1.6 patients/100,000 individuals/year [2]. Data of FDA AERS (Adverse Event Reporting System database) are 0.3-2.2 cases of myopathy and $0.3-13.5$ rhabdomyolysis cases in $1,000,000$ prescribed statins [3].

Rhabdomyolysis is rare adverse effect of statin therapy occurring in less than $0.1 \%$ of patients [2], and mortality rate is approximately 0.15 deaths $/ 1$ million prescribed statins [4]. Prediction of patients with tendency to develop complications is difficult, since the association of plasma concentrations and side effects is not linear [5]. Higher doses are associated with higher risk of adverse effects. The factors increasing the plasma statin concentration increase the risk of rhabdomyolysis. These include renal diseases, hepatic insufficiency, age over 80 years, diabetes, hypothyreosis, genetic factors and interactions with other drugs. The most frequent drugs affecting the statin metabolism are presented in Table 2.

Cytochrome P450 (CYP) enzyme system in the liver is responsible for metabolism of multiple drugs, including the statins, with the exception of pravastatin [6]. Pravastatin metabolizes via several pathways, including the isomerization, sulfation, glutathione conjugation 
Table 1. Clinical spectrum of statin-induced myopathy [1]

\begin{tabular}{ll} 
Condition & Definition \\
\hline Myopathy & General term \\
Asymptomatic CK increase & CK level increase without muscular symptoms \\
Myalgia & Pain or weakness of muscles with no CK level increase \\
Myositis & Muscle symptoms with CK level increase $<10 \times$ upper limit \\
Rhabdomyolysis & Muscle symptoms with CK level increase $>10 \times$ upper limit and creatinine increase \\
\hline
\end{tabular}

Table 2. Substances precipitating statin-induced myopathy

Substances
Cyclosporin
Macrolide antibiotics
(erythromycin, clarithromycin)
Antimycotics
(itraconazole, ketokonazol, fluconazole)
Calcium blockers
(diltiazem, verapamil)
HIV protease inhibitors
(ritonavir, nelfinavir, indinavir)
Varfarin
H2 antagonists
(cimetidine, ranitidine)
Omeprazole
Amiodaron
Fibrates
(gemfibrozil > bezafibrate, clofibrate,
fenofibrate)
Niacin
Grapefruit juice

and oxidation, and via CYP enzyme system in a very low percentage (1\%). It is the only statin with excretion via kidneys (approximately $60 \%$ ), according to its hydrophilic properties [7]. These pharmacokinetic characteristics of pravastatin theoretically render it safer in interactions with other medication [8]. Based on data obtained from epidemiological and clinical studies, the combination of any statin and fibrate increases the risk of myopathy usually in the first 12 weeks from the onset of therapy. The incidence of myotoxicity in combined statin-fibrate use is $0.12 \%$ [9]. Although the majority of reports on rhabdomyolysis includes gemfibrozil, some other fibrates (bezafibrate, clofibrate, fenofibrate) are also responsible for rhabdomyolysis cases when combined with statins [10].

In our case, the most probable cause of rhabdomyolysis is an adverse interaction of pravastatin and fenofibrate, along with other existing factors that increase plasma statin concentration, such as age over 80 years, coexisting renal failure and bacterial infection $[11,12]$. Medical management of rhabdomyolysis is focused on aggressive fluid hydration for diuresis stimulation, because myoglobin dilution in tubules prevents generation of toxic myoglobin cylinders and supports their excretion. Our patient responded well to intensive hydration, in addition to other therapy, what all resulted in resolution of skeletomuscular symptoms and clinical recovery.

In conclusion, early diagnosis and adequate and intensive therapy may reduce the morbidity and mortality of statin-induced rhabdomyolysis.

\section{Conflict of Interest Statement}

The authors certify that there are no potential conflicts of interest.

\section{REFERENCES}

1. Pasternak RC, Smith SC Jr, Bairey-Merz CN, Grundy SM, Cleeman II, Lenfant C; American College of Cardiology; American Heart Association; National Heart, Lung and Blood Institute. ACC/AHA/NHLBI clinical advisory on the use and safety of statins. Circulation. 2002; 106:1024-8

2. Law M, Rudnicka AR. Statin safety: a systematic review. Am J Cardiol. 2006; 97:52C-60C.

3. Davidson MH, Clark JA, Glass LM, Kanumalla A. Statin safety: an appraisal from the Adverse Event Reporting System (AERS). Am J Cardiol. 2006; 97(8A):32C-43C.

4. Thompson PD, Clarkson P, Karas RH. Statinassociated myopathy. JAMA. 2003; 289:1681-90.

5. Krum H, Martin J. Cytochrome p450 Interactions within the HMGCoA reductase inbitor class: are they clinically relevant? Drug Saf. 2003; 26:13-21.

6. Shitara Y, Sugiyama Y. Pharmacokinetic and pharmacodynamic alterations of 3-hydroxy-3-methylglutaryl coenzyme A (HMG-CoA reductase inhibitors: drug-drug interactions and interindividual differences in transporter and metabolic enzyme functions. Pharmacol Ther. 2006; 112:71-105.

7. Haria M, McTavish D. Pravastatin: a reappraisal of its pharmacological properties and clinical effectiveness in the management of coronary heart disease. Drugs. 1997; 53(2):299-336. 
8. Evans M, Rees A. Effects of HMG-CoA reductase inhibitors on skeletal muscle: are all statins the same? Drug Saf. 2002; 25(9):649-63.

9. Shek A, Ferrill MJ. Statin-fibrate combination therapy. Ann Pharmacother. 2001; 35:908-17.

10. Jones PH, Davidson MH. Reporting rate of rhabdomyolysis with fenofibrate + statin versus gemfibrozil + any statin. Am J Cardiol. 2005; 95:120-2.
11. Finsterer J, Zuntner G. Rhabdomyolysis from simvastatin triggered by infection and muscle exertion. South Med J. 2005; 98(8):827-9.

12. Betrosian A, Thireos E, Kofinas G, Balla M, Papanikolaou M, Georgiadis G. Bacterial sepsis-induced rhabdomyolysis. Intensive Care Med. 1999; 25:469-74.

\title{
Rabdomioliza izazvana kombinacijom statina i fibrata: prikaz bolesnika
}

\author{
Tanja L. Jozić1, Branka M. Terzić ${ }^{1}$, Predrag M. Mitrović , Jasminka D. Kostić1, \\ Marko Z. Milanov³, Milena M. Stojanović2 ${ }^{2}$ Milika R. Ašanin² \\ ${ }^{1}$ Klinika za kardiologiju, Klinički centar Srbije, Beograd, Srbija; \\ ${ }^{2}$ Medicinski fakultet Univerziteta u Beogradu, Beograd, Srbija; \\ ${ }^{3}$ Urgentni centar, Klinički centar Srbije, Beograd, Srbija
}

\section{KRATAK SADRŽAJ}

Uvod Rabdomioliza je retka, ali teška i potencijalno fatalna neželjena reakcija primene statina koja može da se razvije u bilo koje vreme tokom lečenja bolesnika. Odlikuje je masivna destrukcija mišića udružena s velikim porastom nivoa kreatin-kinaze (CK), koji vodi do mioglobinurije i moguće akutne insuficijencije bubrega. Kombinovana primena statina i fibrata povećava rizik od rabdomiolize, naročito kod osoba starije životne dobi i obolelih od dijabetesa.

Prikaz bolesnika Muškarac star 81 godinu primljen je u Koronarnu jedinicu Urgentnog centra Kliničkog centra Srbije s kliničkom i elektrokardiografskom slikom akutnog infarkta miokarda prednjeg zida komplikovanog edemom pluća. Laboratorijske analize pri prijemu pokazale su povišene vrednosti kreatinina u serumu - $179 \mu \mathrm{mol} / \mathrm{l}$ i uree $-9,2 \mathrm{mmol} / \mathrm{l}$ (procenjena jačina glomerulske filtracije: $32 \mathrm{ml} / \mathrm{min} / 1,73 \mathrm{~m}^{2}$ ), CK $309 \mathrm{U} / \mathrm{l}$ (drugog dana $3476 \mathrm{U} / \mathrm{l}$ ) i mešovitu hiperlipidemiju (ukupni holesterol 10,3 mmol/l; HDL-holesterol 2,26 mmol/l; trigliceridi 4,85 $\mathrm{mmol} / \mathrm{l}$ ). Bolesnik je lečen preparatima za trombolizu (alteplaza), antikoagulantnom i dvojnom antitrombocitnom terapijom, diureticima, organskim nitratima, inhibitorima angiotenzin-konvertujućeg enzima (ACE), antibioticima i inhibitorima protonske pumpe. Sedam dana je primao i kombinaciju pravastatina u dozi od $20 \mathrm{mg}$ i fenofibrata u dozi od $160 \mathrm{mg}$, koja je prekinuta nakon pojave bolova i slabosti u mišićima i značajnog porasta nivoa CK na $7080 \mathrm{U} / \mathrm{l}$ (gornja granica $200 \mathrm{U} / \mathrm{l}$ ), bez značajnog pogoršanja funkcije bubrega. Nakon prekida terapije došlo je do normalizacije vrednosti CK i poboljšanja kliničkog stanja.

Zaključak Kombinovana primena statina i fibrata zahteva strogu kliničku kontrolu i praćenje promena koncentracije CK i transaminaza. Porast nivoa CK za četiri ili više puta iznad normale zahteva prekid terapije. Pored toga, bolesnike treba savetovati da odmah prijave bilo kakve bolove u mišićima, osetljivost, slabost ili grčeve.

Ključne reči: rabdomioliza; statini; fibrati 